QUALITY

Volume 6, Nomor 2, 2018: 14-22

\title{
MANAJEMEN FASILITAS TERHADAP PROGRESIVITAS SISWA
}

\author{
Ahmad Sauqil Jazil \\ IAIN Kudus, Kudus, Indonesia \\ sauqiljz@gmail.com \\ Achmad Ali Fikri \\ IAIN Kudus, Kudus, Indonesia \\ fikri@stainkudus.ac.id
}

\begin{abstract}
Abstrak
Penelitian ini bertujuan untuk mengetahui dan mendeskripsikan bagaimana pengaruh manajemen fasilitas terhadap progresivitas siswa. Penelitian ini menggunakanan pendekatan kualitatif deskriptif, penelitian kualitatif merupakan analisa pengupayaan kehidupan sosial dengan gambaran sosial yang terjadi menurut interpretasi informan. Fungsi utama penelitian ini adalah untuk mengambarkan ilmu pengetahuan dan memperbaiki praktik. Selain itu pendekatan kualitatif menghasilkan katakata deskriptif secara tertulis atau lisan dari orang yang berperilaku yang dapat diamati dan diarahkan pada latar dan individu yang holistik. Pendekatan deskriptif merupakan penelitian yang bertujuan dalam mendeskripsikan suatu fenomena sebagaimana adanya waktu penelitian dilakukan. Pengumpulan data mengunakan prosedur wawancara mendalam dengan informan (kepala Madrasah MI Manbaul Ulum Pulodarat dan para guru serta pegawai), hal ini dilakukan untuk mendeskripsikan bagaimana pemanfaatan warga sekolah sarana dan prasarana yang tersedia secara efektif. Selain itu peneliti juga mengunakan teknik observasi untuk melihat langsung bagaimana proses pembelajaran dan interaksi sosial antar warga sekolah, dan menggunakan studi dokumentasi.
\end{abstract}

Kata Kunci: manajemen fasilitas, progresivitas siswa

\begin{abstract}
This study aims to determine and describe how the influence of facility management on student progression. This study uses a descriptive qualitative approach, qualitative research is an analysis of the efforts of social life with a social picture that occurs according to the informant's interpretation. The main function of this research is to illustrate science and improve practice. Besides the qualitative approach produces descriptive words in writing or verbally from people who behave that can be observed and directed at a holistic setting and individual. Descriptive approach is a research that aims to describe a phenomenon as it was when the research was conducted. Data collection using in-depth interview procedures with informants (Madrasah MI Manbaul Ulum Pulodarat head and teachers and staff), this was done to describe how to use the school community facilities and infrastructure available effectively. In addition, researchers also use observation techniques to see firsthand how the learning process and social interaction between school residents, and use documentation studies.
\end{abstract}

Keywords: facility management, student progressivity 


\section{A. PENDAhULUAN}

Manajemen berasal dari kata kerja "manage" kata ini, menurut kamus the random house dictionary of the English language, college edition, berasal dari bahasa Italia" manegg (iare)" yang bersumber pada perkataan latin "manus" yang berarti "tangan". Secara harfiah manegg (iare) berarti "menangani atau melatihkuda", sementara secara maknawiyah berarti "memimpin, membimbing atau mengatur". Ada juga yang berpendapat bahwa manajemen berasal dari kata bahasa Inggris "to manage" yang sinonim dengan to hand, to control, dan to guide (mengurus, memeriksa, dan memimpin). Untuk itu, dari asal kata ini manajemen dapat diartikan pengurusan, pengendalian, memimpin, atau membimbing. ${ }^{1}$

Manajemen merupakan proses pendayagunaan semua sumber daya dalam rangka mencapai sebuah tujuan yang ditetapkan. Pendayagunaan yang mmelalui proses perencanaan, pengorganisasian, pengarahan, dan pengawasan disebut manajemen.2 Manjemen bisa dikatakan suatu perencanaan dalam pengaturan sebuah organisasi untuk mencapai sebuah tatanan organisasi yang ideal. Sebuah manajemen sangat diperlukan agar semua tujuan organisasi itu bisa berjalan dengan baik sesuai dengan keinginan bersama. Dalam mencapai sebuah tujuan tersebut ada banyak cara dan bagian - bagian yang harus di lalui sehingga semuanya harus membutuhkan sebuah proses dan tidak bisa langsung atau instan.

Di lingkungan sekolah ataupun madrasah ada beberapa manjemen yang harus diperhatikan dalam mencapai tujuan dari madrasah tersebut, diantaranya manajemen siswa, manajemen keuangan, manajemen sarpras, manajemen kurikulum, manajemen tata usaha dan lain sebagainya.

Menuru Suharsimi (2008:4) menyatakan bahwa Manajemen pendidikan adalah suatu kegiatan atau rangkaian kegiatan yang berupa proses pengelolaan usaha kerjasama sekelompok manusia yang tergabung dalam organisasi pendidikan, untuk mencapai tujuan yang telah ditetapkan sebelumnya, agar efektif dan efisien.

Salah satu bagian manajemen pendidikan yang sangat penting yaitu manajemen sarana prasarana dan fasilitas madrasah. Hal ini dikatakan sangat

\footnotetext{
${ }^{1}$ Daryanto, Administrasi dan Manajemen Sekolah, PT Rineka Cipta, Jakarta, 2013, Hal. 40

2 Ibrahim Bafadal,Manajemen Perlengkapan Sekolah Teori dan Aplikasinya, PT Bumi Aksara, Jakarta, 2004. Hal. 1
} 
penting karena sebuah madrasah dikatakan bagus yang pertama terlihat adalah sebuah fasilitas yang bagus mulai dari bangunan gedung, fasilitas olahraga, fasilitas pendidikan dan fasilitas-fasilitas lainnya yang terlihat jelas oleh mata. Setiap satuan pendidikan formal dan non formal menyediakan sarana dan prasarana yang memenuhi yang memenuhi keperluan pendidikan sesuai dengan pertumbuhan dan perkembangan potensi fisik, kecerdasan intelektual, sosial, emosional, dan kewajiban peserta didik. ${ }^{3}$

Fasilitas merupakan segala sesuatu yang dapat memudahkan dan melancarkan pelaksanaan suatu usaha (Wahyuningrum, 2004:4). Pengelolaan atau manajemen fasilitas sekolah memang harus diperhatikan mulai dari pengadaan, perawatan dan perbaikan hingga pengembangan. Karena sebuah fasilitas harus mempunyai fungsi yang jelas dan menguntungkan kepada madrasah tersebut. Madrasah juga di tuntut untuk meningkatkan mutu pendidikan dengan adanya sarana dan prasarana di madrasah. Dalam menciptakan sebuah tujuan itu maka pemerintah menetapkan peraturan Pemerintah No. 19 Tahun 2005 tentang standar nasional pendidikan yang menyangkut standar sarana dan prasarana secara nasional pada Bab VII Pasal 42 yang berbunyi ;

a. Setiap satuan pendidikan wajib memiliki sarana yang meliputi perabot, peralatan pendidikan, media pendidikan, buku dan sumber belajar lainnya, bahan habis pakai, serta perlengkapan lain yang diperlukan untuk menunjang proses pembelajaran yang teratur dan berkelanjutan.

b. Setiap satuan pendidikan wajib memiliki prasarana yang meliputi lahan, ruang kelas, ruang pimpinan satuan pendidikan, ruang pendidik, ruang tata usaha, ruang perpustakaan, ruang laboratorium, ruang bengkel kerja, ruang unit produksi, ruang kantin, instalasi daya dan jasa, tempat berolah raga, tempat beribadah, tempat bermain, tempat bereaksi, dan ruang/tempat lain yang diperlukan untuk menunjang proses pembelajaran yang teratur dan berkelanjutan. ${ }^{4}$

Pada era zaman now fasilitas yang harus diperhatikan adalah dari teknologi, hal ini dikarenakan sebuah informasi dan pertukaran data semuanya menggunakan

\footnotetext{
${ }^{3}$ Undang-Undang Republik Indonesia No 20 tahun 2003 tentang sistem pendidikan Nasional

${ }^{4}$ Peraturan Pemerintah Tentang Standar Nasional Pendidikan No. 32 Tahun 2013
} 
internet dan mungkin ke depan akan berkembang pada sistem android. Untuk itulah sebuah madrasah di harapkan agar menekankan pada manajemen fasilitas pendidikan. Selain itu dengan adanya fasilitas pendidikan yang terbaru dan mempunyai daya manfaat tinggi tentunya akan mengakibatkan sebuah penilaian baik dari masyarakat dan dapat menarik banyak siswa untuk masuk di madarasah tersebut.

Sebelum ada ide-ide pembaruan fasilitas di MI Manbaul ulum, siswa yang masuk dimadrasah ini sangatlah minim karena; pertama, warga masyarakat berpikir bahwa di madrasah mempunyai banyak pelajaran sehingga anak kesulitan belajar. Kedua, lulusan MI tidak bisa bersaing ataupun mendaftar di sekolah negeri. Ketiga, bangunannya terlalu tua. Oleh sebab itu dimasa itu orang tua kurang berminat mendaftarkan anaknya ke Madrasah ini.

Di MI Manbaul Ulum pada waktu 5 tahun sebelum adanya peningkatan fasilitas setidaknya hanya ada siswa yang mendaftar dengan rata-rata 8-12 siswa dan jika MI membuat program selalu saja di ikuti SD. Salah satu contoh program yang di ikuti SD adalah pembacaan asmaul husna istighosah. Mengingat masalah siswa yang sedikit itulah kemudian berdasarkan rapat para guru dan pegawai untuk membuat sebuah terobosan yang sulit di ikuti oleh SD dengan meningkatkan fasilitas madrasah lewat komputer dan sarana olahraga dengan tujuan meningkatkan jumlah siswa yang mendaftar di MI manbaul ulum pulodarat. Dan akhirnya pada tahun 2013 di rintislah pembenahan sarana olahraga dan pembangunan sebuah laboratorium sekolah yang di ikuti pembangunan perpustakaan. Dengan adanya latar belakang masalah diatas maka penulis membuat judul Manajemen Fasilitas Terhadap Progresivitas Siswa MI Manbaul Ulum Pulodarat.

\section{B. HASIL PENELITIAN DAN PEMBAHASAN}

Penelitian ini menggunakanan pendekatan kualitatif deskriptif, Sudaryono (2017) berpendapat bahwa pada suatu penelitian kualitatif merupakan analisa pengupayaan kehidupan sosial dengan gambaran sosial yang terjadi menurut interpretasi informan. Fungsi utama penelitian ini adalah untuk mengambarkan ilmu pengetahuan dan memperbaiki praktik. Selain itu Bogdan dan Taylor (Wiyono, 2007) berpendapat bahwa pendekatan kualitatif menghasilkan dari suatu penelitian berupa katakata deskriptif secara tertulis atau lisan dari orang yang berperilaku yang 
dapat diamati dan diarahkan pada latar dan individu yang holistik. Pendekatan deskriptif merupakan penelitian yang bertujuan dalam mendeskripsikan suatu fenomena sebagaimana adanya waktu penelitian dilakukan (Wiyono, 2007).

Pengumpulan data mengunakan prosedur wawancara mendalam dengan informan (kepala Madrasah MI Manbaul Ulum Pulodarat dan para guru serta pegawai), hal ini dilakukan untuk mendeskripsikan bagaimana pemanfaatan warga sekolah sarana dan prasarana yang tersedia secara efektif. Selain itu peneliti juga mengunakan teknik observasi untuk melihat langsung bagaimana proses pembelajaran dan interaksi sosial antar warga sekolah, dan menggunakan studi dokumentasi.

Pembahasan hasil penelitian merupakan kajian terhadap hasil temuan yang ada hubungannya dengan jawaban terhadap pertanyaan penelitian. Berdasarkan hasil pengolahan data diatas, maka hipotesis yang berbunyi "terdapat pengaruh yang signifikan antara manajemen fasilitas pendidikan dengan progresifitas siswa di MI Manbaul Ulum" dapat teruji keberlakuannya, dalam arti bahwa penelitian ini mampu menjawab kebenaran hipotesis penelitian. Adapun pembahasan dalam penelitian ini diuraikan secara rinci sebagai berikut:

\section{Pembaruan Fasilitas}

Berdasarkan hasil dari wawancara dari kepala sekolah dan data yang diperolah dari arsip madrasah bahwa madrasah ini mengalami perubahan yang signifikan. Pertama, pada tahun 2009 siswa baru yang mendaftar hanya 9 anak kemudian pada tahun 2010 sebanyak 12 pendaftar dan tahun 2011 sebanyak 11 siswa yang mendaftar. Pemasalahan itu memang tidak seutuhnya karena jumlah anak yang ada di desa pulodarat, melainkan ada masalah yang salah satunya karena fasilitas di madrasah MI sangat kurang.

Pada akhir tahun ajaran 2012 yang dibawah komando kepala madrasah baru, para guru dan pengurus serta pegawai melakukan rapat untuk menemukan solusi agar di tahun yang selanjutnya siswa yang mendaftar di MI Manbaul Ulum mengalami peningkatan. Akhirnya, diputuskan untuk memperbaiki fasilitas madrasah, diantaranya: 
a. Memperbaiki faisitas kelas

Fasilitas pertama diperbaiki di madrasah ini dimulai dari fasilitas kelas yakni menambah 2 kelas baru di belakang gedung lama. Penambahan ini dilakukan berdasarkan sumbangan dari berbagai donatur yang dibantu dengan bantuan dari kabupaten.

Disamping itu juga mengadakan sebuah pembelian sebuah proyektor dan sound sebagai penujang media pembelajaran, agar anak lebih semangat untuk belajar dan tidak bosan.

b. Memperbaiki fasilitas lapangan

Perbaikan kedua yang dilakukan adalah lapangan tempat untuk para siswa berolah raga dan bermain saat istirahat. Sebelumnya anak-anak jika berolahraga harus berjalan jauh ke desa tetangga untuk menikmati lapangan sepakbola, akan tetapi sekarang sudah mempunyai lapangan sendiri di depan gedung baru yang cukup lebar. Lapangan dibelakang biasa di gunakan untuk upacara dan olahraga, walaupun smentara masih berlantaikan tanah akan tetapi sudah cukup lebar jika digunakan untuk bermain anak-anak saat istirahat.

c. Mengadakan berbagai ekstrakurikuler

Setelah fasilitas kelas dan lapangan, perbaikan yang di coba adalah mengembangkan ekstrakurikuler. ekstra tersebut diawali melalui ekstra pramuka yang mendatangkan para alumni yang berkompeten dan di tahun pertamanya berhasil menyabet juara harapan 2 putri tingkat kuaran kecamatan pecangaan.

d. Membuat pengadaan komputer

e. Di MI Manbaul Ulum dulunya tidak mempunyai komputer sama sekali, yang ada hanyalah laptop satu dan dalam keadaan yang rusak berat. Seiring berjalanya waktu dan tuntutan pengiriman data madrasah yang serba online maka madrasah mencari tenaga TU yang lebih segar dan berkompeten.

Setelah berhasil mendapatkan TU yang mengetahui sedikit tentang komputer maka atas usulannya diadakan sebuah ekstra komputer yang pertama dengan 4buah komputer yang dipakai bergatian. 
Dengan adanya ekstra komputer para alumni juga mendapatkan sebuah predikat dari para guru TIK di tingkat SMP/MTs karena lulusan dari MI Manbaul Ulum langsung siap pegang komputer tanpa ragu lagi. Hal ini disebabkan karena di MI siswa sudah dilatih komputer sehingga menjadi terbiasa di sekolah tingkat selanjutnya.

Atas dasar itulah para orang tua sudah mulai menghapus pola pikir jika lulusan MI tidak hanya bisa mendaftar di swasta saja akan tetapi di sekolah negeri juga bisa, bahkan sudah banyak yang lulusan MI mendapatkan juara kelas.

Setelah dilakukan beberapa pembaruan di beberapa sektor, alhamdulillah di tahun 2013 berhasil memperoleh siswa sebanyak 29anak. Dan prestasi peningkatan siswa tersebut masih bertahan hingga saat ini.

2. Prestasi Belajar

Secara umum prestasi belajar adalah tingkat kemampuan yang dimiliki peserta didik setelah berusaha untuk melaksanakan kegiatan belajar. Kemampuan tersebut dimaksudkan sebagai kemampuan yang lebih baik dari sebelumnya.

Menurut Subandijah "prestasi belajar adalah penampilan pencapaian peserta didik dalam suatu bidang studi, berupa kualitas dan kuantitas hasil kerja peserta didik selama periode waktu yang telah ditentukan yang diukur dengan tes standar".5

Prestasi yang diperoleh oleh MI Manbaul ulum sebelum dilakukan pembaruan tidak mendapatkan prestasi apa-apa, akan tetapi setelah dilakukannya perubahan. Seperti yang ada dalam pepatah "Jer Basuki Mawa Bea" yang artinya untuk mencapai keberhasilan diperlukan biaya atau pengorbanan. Sedikitnya ada beberapa prestasi yang di persembahkan oleh para siswa untuk MI Manbaul Ulum Pulodarat, diantaranya;
a. Juara 2 Cerkas tingkat KKMI
b. Juara 1 Lomba PAI tingkat KKMI
c. Juara 3 Pidato Bahasa Arab tingkat kabupaten

\footnotetext{
${ }^{5}$ Subandijah,Pengembangan dan Inovasi Kurikulum. Rajawali Press, Jakarta, 1993. Hal. 193
} 


\section{d. Juara 2 Pramuka Putri Kuaran Pecangaan \\ e. Juara 1 Lari cepat Putri tingkat KKMI \\ f. Juara III Lari Cepat Putra tingkat KKMI}

Menurut Witherington bahwa hal-hal yang dapat menunjang prestasi belajar adalah meliputi:
a. Mengadakan selalu adanya situasi belajar yang baik
b. Penguasaan alat-alat intelektual yang penting
c. Periode latihan yang terpencar
d. Mempelajari keseluruhan yang mengandung arti
e. Ulangan yang aktif
f. Mempergunakan alat-alat bantu visual
g. Memberikan perhatian yang cukup kepada soal-soal
h. Menyesuaikan tempo belajar dengan kapasitas belajar ${ }^{6}$

Itulah beberapa hasil pembaruan sebuah fasilitas di MI Manbaul Ulum yang meningkatkan sebuah progresifitas siswa di MI Manbaul Ulum.

\section{KESIMPULAN}

Sebuah keberhasilan itu tidak terlepas dari sebuah pengorbanan. Sebuah pengorbanan juga tidak akan berarti tanpa kekompakan dan bantuan dari berbagai pihak.

Keberhasilan di MI Manbaul Ulum bisa terlaksana sesuai dengan tujuan dan harapan karena sebuah manajemen yang baik di awal tahun. Manajemen tersebut diawali dengan sebuah rapat kemudian ditindak lanjuti oleh bagian-bagian sesuai dengan tugas dan tanggung jawabnya masing-masing.

Sebuah sekolah memang sangat penting adanya sebuah manajemen, mulai dari manajemen kepala sekolah, manajemen pegawai, manajemen fasilitas dan manajemen lainnya. Jika manajemen tersebut berjalan dengan baik tentunya dalam meraih harapan dan cita-cita bersama tidak akan sulit.

\footnotetext{
${ }^{6}$ Witherington, H.C, Teknik-Teknik Belajar dan Mengajar, Jemmars, Bandung, 1986. Hal. 50-51
} 


\section{DAFTAR PUSTAKA}

Subandijah,Pengembangan dan Inovasi Kurikulum, Rajawali Press:Jakarta, 1993

Peraturan Pemerintah Tentang Standar Nasional Pendidikan No. 32 Tahun 2013

Undang-Undang Republik Indonesia No 20 tahun 2003 tentang sistem pendidikan Nasional

Ibrahim Bafadal,Manajemen Perlengkapan Sekolah Teori dan Aplikasinya, PT Bumi Aksara: Jakarta, 2004

Daryanto, Administrasi dan Manajemen Sekolah, PT Rineka Cipta: Jakarta, 2013

Witherington, H.C, Teknik-Teknik Belajar dan Mengajar, Jemmars:Bandung,1986 